\title{
Öyvind Fahlström's Bord: Visual devices in poetry
}

\section{Eva Lilja*}

\begin{abstract}
The poet and artist Öyvind Fahlström (1928-1976) was the leader of the Scandinavian avant-garde during the fifties and the beginning of the sixties. He wrote his only collection of poetry Bord [Tables] in 1952-1955, but it was not published until 1966. In this book he applies the aesthetic ideas of his two manifestos - signification is what matters in poetry but signification emanates out of the visual materiality of letters and the sounds of speech. Bord contains advanced visual poetry as well as sound poetry. We may notice that the same tools for description and analysis can be utilized for both these modalities, something that can be explained with the help of gestalt psychology and the image schemas of cognitive poetics.

Fahlström's poem "Den svåra resan" ["The hard journey"] is a three-pages score for speech choir and a beautiful visual poem as well. A harmonious, strict picture contrasts to the turbulent sounds. What you see and what you hear express different moods and supply different significations.

The printed picture of elder free verse typically has a straight left margin and a wavering right one. After Fahlström, poets more and more tended to pattern the whole page. With time, Fahlströms ideas met with American language poetry, creating a special quality we recognize in contemporary poetry.
\end{abstract}

Keywords: Öyvind Fahlström, concretism, The Swedish fifties, gestalts, cognitive schemas, premodality, visual devices

\section{Introduction}

A piece of art presents various devices to manipulate time and space. Formerly, temporality dominated poetry, but during the last century the visuality of a poem has also become an important feature. The futurist and the dada movements invented visual as well as sound poetry. This happened in 1912-1916 during the First World War, in a period when pictorial art developed rapidly with a series of experiments. Painting was the predominant art form of that time and influenced other kinds of art with its boldness. After the war, dada was declared dead but it never really disappeared.

* Author's address: Eva Lilja, Department of Literature, History of Ideas, and Religion, University of Gothenburg, Box 200, SE 40530 Göteborg, Sweden, email: eva.lilja@lir.gu.se. 
Dada aesthetics did not influence Swedish poetry until around 1950, when the work of Öyvind Fahlström (1928-1976) became decisive. Fahlström was a poet and a well-known international artist. He wrote most of his poems in the beginning of the fifties, and this literary contribution became a determining factor for the future of Swedish poetry. However, his poetry was to bold for the period, and it was not even printed until the middle of the sixties when a new dadaism blossomed. In Sweden, this movement was known as 'concretism', and Swedish concretist poems were expansive and noisy in character. They differed a great deal from the German new dada style of the same period with its exquisite look (Gassilewski 1999: 70; Lilja 2006: 422). Some examples are presented below.

The inventive power of this movement cannot be overestimated, and many new methods for making meaning out of words were created. In the sixties, poetry could take the form of paintings, speech choirs, and happenings. These are texts to be seen and heard. Noisy performances are alternated with printed pictures for silent acquirement. Both methods imply close encounters with sound forms as well as pictoriality (Olsson 2005: 65-79). Both work with strong form in combination with vague signification.

\section{Fahlström and his book}

Fahlström was the leader of the Scandinavian avant-garde for a long time. He was born in Sao Paulo, Brazil, and was the son of a Norwegian father and a Swedish mother. In July 1939 he was sent to Stockholm in order to visit some relatives, and because of the outbreak of World War II he had to stay there. In spite of his international background, he became a Swedish school boy. After the war he studied art history and archaeology in Stockholm, and 1950-1955 he went to work as a writer, critic and journalist (Hjelmstedt 2007: 173-175).

His first public appearance was in 1953, in the exhibition of "Opera", which was a room-sized felt-pen drawing. In 1956 Fahlström moved to Paris and lived there for three years, but he remained a dominant leader of the Scandinavian avant-garde. With time, the Swedish scene became too limited for him, and in 1961 he settled down in New York, but even through the sixties he spent much time in Stockholm. He also represented Sweden in the 1964 Venice Biennale. Around 1970 he had a number of solo exhibitions in New York and he is also represented at the Museum of Modern Art (MOMA). Especially influential was his use of the game as a basic pattern for his art. He developed art forms like happenings and performance in cooperation with, 
among others, Andy Warhol, Robert Rauschenberg and John Cage. Fahlström also developed the Swedish radio drama into a new artfulness. A favourite is Fåglar i Sverige [Birds in Sweden] (1963), a half hour long fantasy of fantastic sounds. He also made four Swedish films. However, Fahlström's international success meant that his work with texts increasingly gave room for painting (Hjelmstedt 2007: 176-179; Bäckström 2011: 77-81).

Mostly, Fahlström's art works commented on social and political questions - like Minneslista till Dr Schweitzers sista uppdrag [Memorandum to Dr Schweitzer's last mission] (1964), a book that was turned into an exhibition but he was also influenced by fairy tales, nonsense poetry, fables, pop art and the French situationists. Fahlström died of cancer in 1976 at the age of forty-eight.

Fahlström actually began writing as a surrealist. In 1949 he wrote the unpublished poems collected under the title Trumpeten $i$ stjärten (1949) [The Trumpet in the Bottom]. Here he was inspired by, among others, Marquis de Sade. ${ }^{1}$ Even if he left surrealism a couple of years later, it is possible to trace this movement in all of his works (Gassilewski 1999: 67),

Fahlström published only one book of Swedish poetry, Bord [Tables] 1966, with texts written between 1952 and 1955. The very title, Bord, is developed out of two Swedish words, 'bokstav' [letter] and 'ord' [word], combined into 'Bord' [or 'Table']. In 1954, his first manifesto was printed in a small avantgarde journal. More about this below! The poems in Bord can be looked upon as applications of his aesthetic ideas in the manifesto, but this is also good poetry - visual poetry and sound poetry. Here we meet with a chaotic world where the human body dominates the circumstances. Fahlström's lifelong interest in scatology, pornography, the monstrous, and the body was already fully developed (Bäckström forthcoming: 1). The language works with repetitions and permutations into delirium. Incantation, nonsense, and all kinds of low language are used, something rare back in the 1950s (Bäckström 2012: 97-100).

The poems in Bord can be grouped in accordance with their use of visuality and/or acoustic means. The main text, "Det stora och det lilla" ["The big and the small"], fifteen pages long, expands from a few recurring themes, for example some sharks and a guy called KALLE HAVET [could be 'Charlie the Sea', or 'the cold sea']. Some of the themes run all through the book, like "Massif Central" - "Massif Central / halstrat i brinnande vin" ["Massif Central

1 The manuscript of this poetry collection belongs to the Fahlström collection at the Royal library in Stockholm. Another unpublished collection of poems is "Borborygmernas fall" ["The fall of the Borborygmi”, manuscript lost] (Bäckström forthcoming: 1; Olsson 2005: 48). 
/ fried in burning wine"]. One passage replaces all vowels with an 'i', another passage uses an ' $y$ '. All of the (large) page surfaces are in play with the help of marginal stanzas, columns, capitals and so on. Sometimes the print makes decorative figures. ${ }^{2}$ See picture 1 in the Appendix.

"MOA (1)" ('Moa' is a girl's name) looks more like a score in music than traditional poetry with its ten columns of combinations and permutations. It may be read from the left to the right or, if you like to, downwards column by column (Olsson 2005: 271) (see Picture 2). The choice creates different word combinations making different possible meanings. "Nyårsklockorna" ("New Year's bells") develops a similar idea. The first four pages investigate the vowels in hovering word fragments (Gassilewski 1999: 69). But if "MOA (1)" doesn't look that inviting to the reader, "Nyårsklockorna" seems tempting in its visual beauty (see Picture 3).

The two "Topp-timm" poems are primarily sound poetry just like the four "Bobb" poems. "Morgon i rådhuset" ["Morning in the town hall"] combines untidy rhythms with a harmonious printed image. The poem suggests that there are too many clubs and too many farmers in the Town Hall. They keep joking, swimming, and dining with their foxhounds. The 'I' of the poem has problems with his composite feelings. This might be a satire about local democracy and an old-fashioned man's role, both of them functioning badly. The harmonious printed image is undermined by a disharmonious sound image and rather impolite meanings (Lilja 2009: 283-286) (see Picture 4). In this poem the printed image shows a spiral consisting of six swings - it is beautifully balanced, aiming at visual symmetry. The first three lines of each line group grows longer and longer before the arresting short lines. The left margin is straight but three half stanzas don't begin until somewhere in the middle of the page and each time it has moved a little further to the right. At the bottom of the page the indentation reaches about two centimetres longer than in the beginning - this poem stands broad-bent. Like a chauvinist farmer? (Lilja 2014: 147-151).

Below I will delve deeper into "Den svåra resan" ["The hard journey"], a three pages score for speech choir AND a beautiful visual poem. But before that, we need to look at some aesthetic ideas.

2 Olsson 2005, p. 281f. Olsson makes an extensive description of "Det stora och det lilla" p. 409-416. 


\section{The aesthetics in Bord}

Fahlström is famous for his two manifestoes of concretist poetry, one published in 1954, and the other one in 1961. We will take a look at both of them. In 1953 he wrote "Hätila ragulpr på fåtskliaben" ("Hipy papy bthuthdththuthda bthuthdy"), a manifesto for concrete poetry, published in Swedish the following year and in English translation in 1968 (Olsson 2005: 45-65).

The first and most important manifesto is "Hätila ragulpr på fåtskliaben", nonsense words meaning 'Happy Birthday' (in Swedish 'Hjärtliga gratulationer på födelsedagen'). The Swedish version as well as the English one is a citation from Winnie-the-Pooh, from the passage where Owl doesn't know how to spell. Fahlström emphasizes that poetic form must have rules, but other rules than those of the tactus versification. He mentions vocal series, vertical parallelisms, marginal stanzas and framing stanzas. Most important is to break all kinds of conventions in order to restore the reader's genuine acquisition. It should be possible to read the poem vertically and diagonally, not only horizontally. The eye should move over the page in the same way as it does in front of an abstract painting.

Fahlström stresses that signification is the aim of poetry. You need materiality - voice and print - to make meaning. His ideas for shaping poetry are spatial as well as temporal, visual as well as auditory in nature. Sequential reading will be prevented by a range of visual devices, something which considerably increases the number of significations. The visual patterns create tensions in relation to conventional meaning, and focus will be transferred to the materiality of the poem. Fahlström establishes poetry as an art form of space AND time, in contrast to Lessing's famous statement of poetry as situated in time (Olsson 2005: 61).

Fahlström considers rhythm to be the basic device in shaping poems because of its bodily origin, the biorhythms. Rhythm is among other things a kind of repetition and it functions in time and in space alike. Fahlström's ideas are applicable to all art forms, music and painting as well as poetry. He is very conscious of the possibilities of different medias, but in the first place he thinks of all kinds of art as performance. In this respect he is about half a century before his time (Olsson 2005: 57-64; Bäckström 2011: 81; Hultberg 1999: 86f).

For many years Fahlström's first manifesto caught no attention. But in the sixties cultural life turned more experimental, and Fahlström wrote a new version of his manifesto, "Bris" ["Breeze"] for the widely spread journal Rondo in 1961. Now he got his well-deserved followers, poets like Åke Hodell and Jarl Hammarberg. 
Once more Fahlström underlines that language signs are random. Meaning always stems from the associations of the reader. This implies that the poem must be shaped in a way that forces the reader to activate his associations. The poet should destroy conventional significations into a polyphony of connections tempting the reader to create a new whole. In this way one could either erase conventional meaning or sharpen it. The most fascination feature of language is that sound and signification have nothing to do with each other, says Fahlström in "Bris".

The poetics in "Bris" describes a new way of thinking about poetics and versification. Over and over Fahlström emphasizes that the poem is its meaning. But he doesn't refer to lexical meaning as signification should emanate out of the sound and sight of words. Meaning is an effect of the play between letters and sounds. This is a turning point in the history of poetics, in a development that started with the Zürich Dada and nowadays is main stream in the poetics of Language materialism.

After moving to New York, Fahlström invented new international languages - his poetics is not limited to Swedish or any existing language. He started from his radio poem Fagglar i Sverige [Birds in Sweden] and shaped the language 'Fåglo' and its more English variety 'Birdo'. In this poem he used transcriptions of bird song transformed according to some self-made rules springing from a game logic. Later on there was a third variety, 'Whammo', shaped out of the expressions of American comics. These home-made languages live in a borderland between image, sound, and performance (Bäckström 2011: 77-81).

\section{Gestalts and schemas}

The poet Fredrik Nyberg writes that sight and hearing work simultaneously when writing a poem. The shapes of letters, words, and pages stand close to what is produced by mouth and ear. Traditionally, audibility has been thought to be the dominant sense in poetry, but this can really not be defended. Eye and ear together control the shaping of a poem, Fredrik Nyberg suggests (Nyberg 2013: 481). There seems to be a reciprocal dependence between senses. To explain this, we may first consider the findings of the school of gestalt psychology a century ago and their so called gestalt laws. 


\section{Gestalts}

Gestalt psychology primarily refers to visual gestalts. Obviously, visual impressions are grouped to attain coherence, be it the same colour or form, or perhaps closeness or similar direction. Temporal perceptions form gestalts through such features as vicinity and similarity. In 1923, Max Wertheimer formulated these universal laws for the first time, demonstrating how the human mind creates gestalts, significant entireties (Ash 1995: 224f).

All reading is determined by the gestalt laws of perception (Tsur 2012: 21). ${ }^{3}$ Common experience will influence how we shape the gestalts - practise may stimulate us to prefer one certain form, and as readers we might apprehend one gestalt but not another. Our solid experience of gestalts can explain why we know when, for example, a piece of music is drawing to its end. Subtle acoustic signals tell us that closure is approaching (Herrnstein-Smith 1968: 41; Arnheim 1957: 323). Completion needs a limit, the borderline of the gestalt. This is true for spatial as well as temporal figures, for smaller and bigger gestalts.

During the past century, gestalt theory has developed in different ways. Classical principles of grouping, like closeness, vicinity and similarity, have had additions like synchrony, common region, uniform connectedness, not forgetting contour completion (Kubovy, Valkenburg 2006). Jean Piaget (1953, 1966: 47-143) studied how babies acknowledged perception schemas with the help of experience, how their schemas were coordinated and developed with time, and also offer a possibility to preserve human experience. Richard Cureton (1992: 190f, 270f) modernised the principles of grouping, referring instead to 'preference rules'. Reuven Tsur adapts the gestalt laws to poetry performance. A main idea of his is the difference between strong and weak gestalts. He also emphasizes how repetition strengthens patterns (Tsur 2008: 111-154, 507; 2009).

Often you hear of 'good gestalts'. The grand old man of Gestalt psychology Karl Koffka points out that 'good' in this case refers to regularity, symmetry, and similarity - qualities supplying salience, conciseness and orderliness, or simply 'Prägnanz' (Tsur 2012: 49). The 'good gestalt' has worked as an important factor in aesthetic thinking (Tsur 2008: 113; Ash 1995: 226).

The gestalt laws are the same independent of art form or medium (Tsur 2008: 154; Kandinsky, Wassily 1926: 110). The same categories work in dance and poetry, music and sculpture. A dancing body is a gestalt just like

\footnotetext{
3 Tsur also adds the importance of short time memory in the reading process. The two together form the reader's rhythmical competence.
} 
the picture and the poem, all of them composed by sets of smaller gestalts (Cureton 1992: 189; Lilja 2014: 78). Obviously, gestalt laws are premodal in character. From the perspective of intermedia studies, this is a crucial point. We can use the same tools for analyzing dance, sculpture, paintings, music, and poetry - visual as well as audible qualities in Fahlström's poems. Gestalts are just as important in audible sequences as in visual ones, and for sure also in tactile ones (Gallace, Spence 2011: 538-561). The gestalt has no objective existence but an intersubjective one (Tsur 2012: 132f). It is easy to agree on its shape even if it is formed in the individual perception.

\section{Image schemas}

Fahlström's poems can be looked upon as visible and audible gestalts formed by mental mechanisms, the so-called image schemas. These schemas provide models that turn the artefact into gestalts, patterns aiming at coherence and significance - they give shape to the gestalt (Rohrer 2005: 171, 173). ${ }^{4}$ An image schema stands for bodily experiences that are transferred into stable patterns of perception (Johnson 1987: xix; different articles in Hampe 2005). Something happens during the passage of perceptions into the mind - image schemas act as a kind of filter in the way from perception to form and signification. They adapt the world to the human being, organising the interplay between mind and world. Image schemas are mental mechanisms that form our experience of the world - including poems. ${ }^{5}$ From this view point, a poem starts as a set of perceptual impulses, what you see and what you hear. More than that, this is an important aspect of how Fahlström regards poetry. Signification will develop in the other end of this process.

The choice of schema happens instinctively, often influenced by the reminiscence of some bodily movement arisen from the actual perceptions. Other important sources are environment and memory (Gibbs 2007: 74; Ash 1995: 115; Lilja 2014: 97f.). You never get in contact with those sensory impulses that do not fit into your schemas. Eyes and ears have seen and heard, but these perceptions are never realized and therefore they get lost (Ash 1995: 115; Lilja 2014: 97f).

\footnotetext{
4 Rohrer stresses that image schemas are recurrent patterns of bodily experience, they preserve the topological structure of the perceptual experience, they operate dynamically in time, and they link sensorimotor experience to conceptualization and language.
}

5 Johnson 1987 demonstrates different cases. 
These schemas occur before a differentiation takes place into visual, audible, and tactile forms - they are premodal. ${ }^{6}$ Image schemas work the same in time and space. ${ }^{7}$ This means that the same patterns are valid for all art forms, dance, sculpture, music, and poetry. We may compare with the Ancient Greek art form mousiké where dance, music and poetry form a whole (Evans forthcoming). Let us remember the poet in the agora moving, playing and reciting, a body in time as well as space.

Visual forms primarily meet as an entirety, and you need some time to see the details. In contrast, temporal forms are first perceived in sequences, but in a next step it is possible to grip their wholeness. Looking at a picture, you will take it in as a whole and later on notice the parts. The opposite holds for temporal art forms like poetry - the ear starts with the segment, and it will take you some time to catch the whole gestalt. Fahlström's visual poems first approach us as expressive pictures that need some time to be considered while the eye wanders from one side to another and back again.

\section{Kandinsky on signification}

Visual qualities as well as speech sounds influence the meaning of a poem. Of course, this kind of signification is subtle and not that easy to describe. It is a matter of associations, similarities, and affects. The same problem turns up in front of an abstract painting, something that might give us some help.

Wassily Kandinsky (1866-1944) is one of the most influential painters in Modernist abstract art. He wrote some books in art theory where he reflects over the possibilities of abstract forms creating meaning, for example Punkt und Linie zu Fläche [Point and Line to Surface] 1926. We may take note of a couple of his viewpoints. He starts with the square of the canvas, the basic surface, Grundfläche (Kandinsky 1955: 131-146). He makes observations concerning directions up and down, where 'down' means the stable ground, but 'up' is expansion and freedom (Kandinsky 1955: 131f). The bottom line works as a transfer of earth, a place where we can stand safely. This is to be compared with the cognitive metaphor MORE IS UP and its depressing opposite

\footnotetext{
6 Johnson and others refer to psychological experiments to prove what they call 'cross-modality' (Johnson 2007: 143).

7 Lakoff and Johnson explains this in terms of brain organization. Time is conceptualized in motion, and the detection of motion has an area in the brain visual system (Lakoff; Johnson 1999: 140 .
} 
downwards (Lakoff, Johnson 1980: 14). Cognitive semantics has ascribed the directions up and down positive and negative signification respectively. In this, cognitive theory supports Kandinsky's ideas, at least concerning the upward direction. Maybe the ambiguous connection between earth and death is the missing link considering the different understandings of the downward direction.

Directions left and right are more complicated in Kandinsky's thinking. The left side is connected to the upward direction but with a weaker expression (Kandinsky 1955: 135). The right side means heaviness, a continuation meeting a border (Kandinsky 1955: 137). This is in accordance with the Western reading direction - you are aiming towards the right side. In a next step, Kandinsky says that 'left' stands for far-away but 'right' means home (Kandinsky 1955: 138).

\section{Black print and sound music}

We have already taken a rapid glance at a couple of the poems in Fahlström's Bord. Now we will go deeper into of one of them, the three pages of "Den svåra resan" ["The hard journey"], probably written as early as 1953 . See picture 5!

\section{Sound music}

This is an impressive visual poem, and at the same time the text makes a score for a speech choir of eighteen voices. Only few of the expressions have any conventional meaning, but you may find a salmon ("lax"), an extract of cat ("kattextrakt"), and a love-making girl called Ulla ("ullaligg"). From these examples you may notice a sharp contrast between soft and hard consonants, explosives like $/ \mathrm{k} /$ and $/ \mathrm{t} /$ beside the soft repeated $/ \mathrm{l} /$. However, the soft and the hissing sounds dominate over the hard explosives in this poem. The eighteen parts of the speech choir restart from the left marginal five times. Every part is supposed to transcend the line break.

The very start exploits a mighty /A/. The harsh repeated "RRA - CKA" is the only task of part 5 and given extra significance with the help of extra big capitals. Today we think of the city "Raqqah", but this was an unknown place in the Swedish fifties. However, 'racka' is the beginning of Swedish 'rackare', 'scoundrel. In the very end it develops into a "TACK" [thank you] also in very big capitals. The word brings along other rough sounds like "ódidakteriodi" 
in part 12 (could be Greek and mean something like 'ways of teaching') not to mention the cats (kattor) and the salmons (laxar) of part 9.

Part 6 takes care of the lovemaking Ulla starting slowly with "jálli" but transforms into a joyful “... lillallugglillallújá” (to be compared with 'hallelujah, 'lilla' means 'small' in Swedish, 'lugg' is a hair style) - part 6 is really signified by melting 1-sounds. Even part 16 works sensually, for example with a 'word' like "mummjújölúll". Part 12 completes in a lonely “...smörgås" (sandwich) while several other parts blurt out with "F-R-F-R-F". I think that the sandwich will drown in the noisy hissing hubbub that finishes the performance.

Firstly, this vivid sound play should be looked upon as a demonstration of what phonemes are able to do if they are freed from lexical signification. Maybe voice 1, exploiting a stubborn quiet /O/, could stand for rest and balance. Also part 4, 8, 11 and 15 exploit one sound only but more noisy and hissing ones like the fricatives 'f', 'sj' and 's'. Consonants in other parts move forwards, more and more determined, during this journey. We travel and it is a hard journey, a landscape of paths /fffff/ (part 4), water /MMMMMMM/ (part 13-14) and stones /BL-BL-BL/ (part 3). ${ }^{8}$ Some dirty corners seem to be present as well.

\section{Black print on white paper}

In the book, "Den svåra resan" uses three pages. The poem moves slowly within harmonious squares. Typography is pure and beautiful inspite of the juicy and woolly character of the sounds, just like the case in many other poems of this book. The figures of the left margin do not belong to the text, but are instructions for the speech choir. To begin with, six parts cling to one sound each, and the repeated letters stretch over the pages as elegant edgings. Long lines contrast to half long and very short ones, capitals contrast to lower-case letters.

As already said, the speech choir starts from the left margin five times. The first turn on the first page balances a text surface of black letters to the left with another to the right. After that a steady movement to the right follows. The second and the third turn move from upper left down to the right, and the fourth and fifth turn transfer the weight to the right side of the page. This motion harmonizes with the ordinary reading direction from the left to the

\footnotetext{
8 Cognitive theory conceptualizes (reading) time, among other possibilities, as walking along
} a path. Lakoff; Johnson 1999: 146. 
right. 'Right' means home and safety, says Kandinsky, but emphasizes an element of confinement in this (Kandinsky 1955: 137).

Long liners in beautiful edgings hold shorter text pieces in a balanced picture. The visual poem lies quietly on the paper. The white surfaces between letters add silence to a reading - the empty paper also supplies rest, tension, balance. "Den svåra resan" possesses many white surfaces to subdue the print.

The one-letter-lines divide the paper into sections, something that disappears in the last third of the poem, where the bottom line is a short one. Part 1 repeats a persistent /O/ until the beginning of turn 4 where it suddenly ebbs out with a surprising /... IPS/. After that the steady edgings come to an end. The very last line (part 13, 14, 15, 17, 18) snorts and murmurs to the right but this is not enough to construct a solid bottom for the visual poem. If we remember Kandinsky's observations concerning directions up and down, this circumstance influences the meaning of the poem. Here there is no steady ground while the tight first line provides an obstacle for upward movements this could mean missing chances.

Quietness dominates the visual impression, but there are some disturbing details, covered reading instructions. Interesting elements are the hyphens that sometimes thin the edgings of letters. A foot note on page 44 tells us that hyphens should be pronounced as 'mute e' (!). Perhaps Fahlström thinks of vowel murmur, but the hyphens serve as pronunciation help as well - without that hyphen you have to gurgle the "GL" and snort the "FMMF". The powerful "RRA - CKA", repeated three times, has a letter size that substantially exceeds the rest - maybe the most visible 'word' will also have the highest volume.

Above I suggested that reading or listening to this poem could be comparable with walking through a landscape making 'a hard journey', as the title says. Remember Fahlström's thesis that meaning is what matters in a poem. Is there a story in "Den svåra resan"? What is this poem doing except elaborating the look of letters and the taste of speech sounds? The quiet motion from the left to the right - could it be understood as development? Maybe the love-making Ulla could be its princess.

If the journey of sounds provided a landscape of stones and water - what does the visual poem convey? Here we are more as in a square garden where the flower borders are harmoniously and strictly spread over the place. I have underlined the opposition between the harmonious, somewhat severe picture and the turbulent sounds of the score. What you see and what you hear express different moods and supply different significations. Typography mediates orderliness but the sound picture is jerky and unclean. We may presume that the quiet picture dominates the poem when silently read and, reversely, the speech choir in the first place elaborates the turbulent sounds. 


\section{Visuality and free verse}

In my analysis, I have shown that the very same text may evoke different schemas depending on temporal or visual modus. Nevertheless, the same schemas occur in both my analyses - the temporal and the visual one. Primarily, I have been looking for the schemas of 'direction' and 'balance'. Both of them are to be found, but they do not occur at the same place in the visual and the temporal poem.

Old-time metered poetry is temporal and acoustic. Free verse was born around the turn of the century 1900, a period when the prices of the printing houses went down and as a consequence poetry changed appearance. In the nineteenth century poems were recited, but in the twentieth, poetry was mostly consumed by reading a book. Visuality does not interest performed poetry, but the picture became more and more important for silent reading. Even then temporal rhythm is evident to the reader, but the printed picture is what meets the eye at a first sight. ${ }^{9}$

The very first experiment in visual poetry, Stéphane Mallarmés poem "Un coup de dés" (1897), moves in diagonals over the opening from the upper left corner down to the lower right one - and we could trace the same motion in "Den svåra resan". This means a gesture of continuation and development, but also much emptiness and white paper. In the Mallarmé tradition you look for the silence of a poem. The page turns into a picture where blank space is just as important as letters. One of the most typical devices of modernist free versification came to be the play between words and silences, letters and white paper. Mallarmés invention of the printed picture coincided with the cubist idea of suspending the difference between time and space in a painting. For example, motion was described by depicting the body in several moments of a movement at the same time. In that way, time was incorporated with space.

During the first half of the twentieth century, free verse mostly uses a typical typography - there is a straight left margin and a wavering right one. During this time, poets worked mainly with temporal rhythms, trying to make them expressive without the means of the tactus. Mainly, they followed the heritage of Antique cola and Old Norse accent versification, adapting both to modern languages. It took time before Mallarmés keen experiment had

9 Olsson makes a valuable survey of the hybrid tradition of pictures and poems (Olsson 2005: 281-389). 
its followers. In the beginning, visuality was used only for some details - this means of versification needed to be developed. ${ }^{10}$

From this perspective, the fifties appears to be a most interesting period. In the Swedish history of poetry, this is a prospering time. Among others, the Nobel Prize winner Tomas Tranströmer published some of his best work, and, not least, the international artist Öyvind Fahlström fought with the stiff Swedish language before he left for New York. The Swedish fifties is a time of fulfilment at the same time as the period prepares for new insights in poetic language.

It took some time before these efforts found any use for following generations. In the eighties, Katarina Frostenson was able to develop concretist findings and reshape them for application in a somewhat more conventional poetry. After that contribution, Swedish verse could use more and more of the concretist inventions, not least visuality. Nowadays, the poet normally utilizes all the page, arranging letters in beautiful patterns to make meaning out of the space between words. In this process, international influences have meant something, but Fahlström's heritage was decisive. Swedish poetry today is especially strong in so-called language materialism, and the historical base of this strength is Fahlström's Bord and his manifestos.

10 For example, Gunnar Ekelöf used pictorial devices in his famous Sent på Jorden [Late on Earth] (1932). Among other things, the very word "guld" [gold] was coloured in golden yellow in the print (Wåhlin 1993: 126). 


\section{References}

Arnheim, Rudolf 1957. Art and Visual Perception: A Psychology of the Creative Eye. London: Faber \& Faber.

Ash, Mitchell G. 1995. Gestalt Psychology in German Culture, 1890-1967. Cambridge: Cambridge UP.

Bäckström, Per 2011. Öyvind Fahlströms konkreta poesi: Materialitet och performance [The Concretist Poetry by Öyvind Fahlström: Materiality and Performance]. In: Aiolos 42, 75-82.

Bäckström, Per 2012. Words as things: Concrete Poetry in Scandinavia. In: Veivo, Harri (ed.), Transferts, appropriations et fonctions de l'avant-garde dans l'Europe intermédiaire et du Nord. Cahiers de la nouvelle Europe, 1767-2538, 16. Paris: L'Harmattan, 89-104.

Bäckström, Per (forthcoming), The Trumpet in the Bottom: Öyvind Fahlström and the Uncanny.

Cureton, Richard D. 1992. Rhythmic Phrasing in English Verse. Harlow: Longman.

Evans, Stephen (forthcoming). "Molpe" and the Performance of Homer.

Fahlström, Öyvind 1966, facs. 1999. Bord [Tables]. Stockholm: Lejd.

Gallace, Alberto; Spence, Charles 2011. To what extent do Gestalt grouping principles influence tactile perception? In: Psychological Bulletin 137, 538-561.

Gassilewski, Jörgen 1999. Efterord [Introduction]. In: Fahlström, Öyvind, Bord [Tables] [facs.]. Stockholm: Lejd, 65-71.

Gibbs, Raymond, W., Jr 2007. Embodiment and Cognitive Science. New York: Cambridge UP.

Hampe, Beate (ed.) 2005. From Perception to Meaning: Image Schemas in Cognitive Linguistics. Berlin: Mouton de Gruyter.

Herrnstein-Smith, Barbara 1968. Poetic Closure. Chicago: Chicago UP.

Hjelmstedt, Lars 2007. Biography. In: Fahlström, Öyvind, Med världen som spelplan [The World as a Game]. Halmstad: Mjellby Art Museum, 173-179.

Hultberg, Teddy 1999. Öyvind Fahlström i etern - Manipulera världen [Öyvind Fahlström on the Air - Manipulating the World]. Stockholm: Swedish Radio.

Johnson, Mark 1987. The Body in the Mind: The Bodily Basis of Signification, Imagination and Reason. Chicago: Chicago UP. 
Johnson, Mark 2007. The Meaning of the Body: Aesthetics of Human Understanding. Chicago \& London: Chicago: UP.

Kandinsky, Wassily 1926, 10. Aufl. 1955. Punkt und Linie zu Fläche: Beitrag zur Analyse der Malerischen Elemente [Point and Line to Surface: A Contribution to the Analysis of Elements in Painting]. Berlin: Verlag Bern.

Kubovy, Michael; Valkenburg, David Van 2006. Auditory and Visual Objects. In: Marco Bertamini; Michael Kubovy (eds.), Human Perception. Aldershot: Ashgate, 97-126.

Lakoff, George; Johnson, Mark 1980. Metaphors We Live By. Chicago \& London: Chicago UP.

Lakoff, George; Johnson, Mark 1999. Philosophy in the Flesh: The Embodied Mind and its Challenge to Western Thought. New York: Basic Books.

Lilja, Eva 2006. Svensk Metrik [Swedish Metrics]. Stockholm: Norstedts.

Lilja, Eva 2009. Towards a Theory of Aesthetic Rhythm. In: Dewey, Tonya Kim; Frog (eds.), Versatility in Versification: Multidisciplinary approaches to metrics. New York: Peter Lang, 273-292.

Lilja, Eva 2014. Poesiens Rytmik: En Essä om Form och Betydelse. [Rhythm in Poetry. An Essay in Form and Signification.] Tollarp: Ariel.

Nyberg Fredrik 2013. Hur låter dikten?: Att bli ved II [The Sound of Poetry: How to become firewood II] Göteborg: UP.

Olsson, Jesper 2005. Alfabetets användning: Konkret poesi och poetisk artefaktion i svenskt 1960-tal [How to Use the Alphabet: Concretist Poetry and Poetic Artefaction in the Swedish Sixties]. Göteborg: OEI editör.

Piaget, Jean 1953. Origins of Intelligence in Children. New York: W.W. Norton \& Company.

Rohrer, Tim 2005. Image Schemata in the Brain. In: Hampe, Beate (ed.), From Perception to Meaning: Image Schemas in Cognitive Linguistics. Berlin: Mouton de Gruyter.

Tsur, Reuven, 2008. Toward a Theory of Cognitive Poetics. 2. exp. ed. Eastbourne: Sussex Academic press.

Tsur, Reuven 2009. Aesthetic Qualities as Structural Resemblance. Divergence and Perceptual Forces in Poetry. URL: http://www.tau.ac.il/ tsurxx/Structural_ Resemblance/within_thine_own.html 
Tsur, Reuven 2012. Poetic Rhythm: Structure and Performance: An Empirical Study in Cognitive Poetics. Brighton: Sussex Academic Press.

Wåhlin, Kristian 1993. guld! guld! [gold! gold!]. In: Dahl, Elena; Lilja, Eva (eds.), Metriken som tolkningshjälp [Metrics as a Means of Interpretation]. Göteborg: CMS, 107-183. 


\section{Appendix}

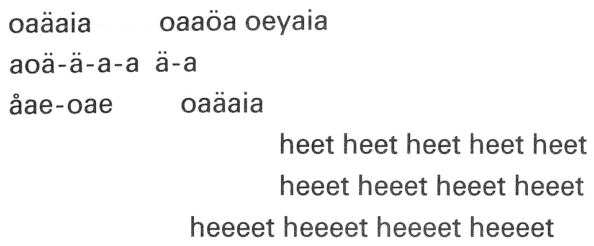

grova säkra nickar

av dom där hästarna

hårdare tjockare och han ska gör dom mest sympatiska

lärda

groaäaia

stoaia uio öieiöa

aäiae åuue

äae-oae stoi uio

stora milda gubbstrimmor finare het het het försvinner i grödan het het het het het het han bärsin sadel het het het het het het påhuvudet het het het het het het het hårdare tjockare het het het het het het het stoi uio het het het het het het

han fick en varm röksmak haieaöa eouu aiae e genom huvudet han vilade det före nicken öeie ie-ä dvs. i en häst öeie ie-ä öeie ie-ä öeie ie-ä öeie som helst hårdare tjockare åae-oae hai eaöa åae-oae åae-oae åae-oae åae-oae åae-oa het het het het het

het het het

het het

stampar vatten för att och håller sin kofitta hårdare tjockare staaae staaae öa öaåia uäa uao oåei oia åae oia åae oia åae oia åae oia ååae oae staaae öa oae oae oae oae oae oae oae oae oae oae oae ae het het het het het het $h$ het het het $h$ het het het het haaaet höat höaåiat huäat huaot hoåeit hoiat håaet hoaet haaaet höat

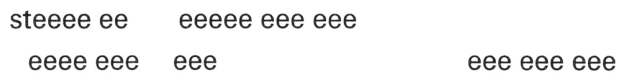


hastam hapar hava hetten höför haatt hooch håhå heller hisin hoko hifi hatta hotjo hacka here hastaaae hööa karlar om världar

tack karlar håfå histi hacka huupp hänä håhå harda here hasan huur hahaj hobot

ljud av badkar som talar och myskdoftande falkar hängande-i kategorier om benen konst salami två-tre karlar livs marginal konst tack två-tre svankig livs marginal cko cko cka cky cko cko cky cko cko cko cky cko cko cko cky ur sina syner uppstår handelsmän för att göra hårda arbeten i livets tjänst och talar med hajar för att se vem de talar med står på en rasande primitiv matta cko cko cke cka cka cke cki cki cki cka cka stigande fallande skala

med stjärnornas väldiga vo voly mma ssor buk tan de un der si na hu vu den hu vu den hu vu den hu vu den

mbo med skärnornas väldiga volummassor bultande under huvudet som björkris står han på sin a sis ta fri a fri mär ken fylls med buk tan de läsk pa pper för att bä ra hans o er hört ly hor da lănga buk ta lan de lung or cko cko cka cky cko cko cky cko cko cko cky cko cko cko cky

tack karlar tack karlar cka-ka-k garvarkluns som ett lik med ett köttben i munnen cka-ka-cka

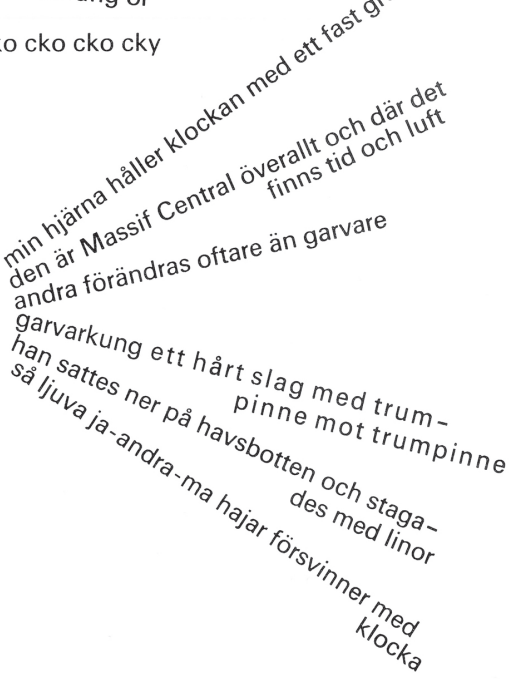

Picture 1. 


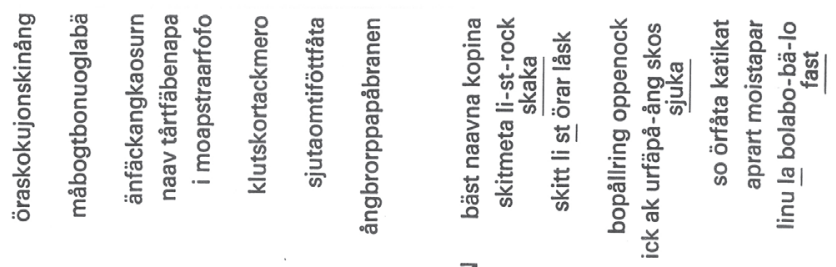

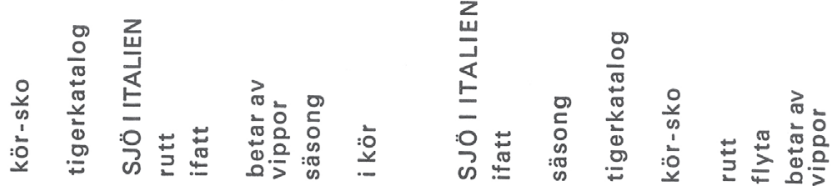

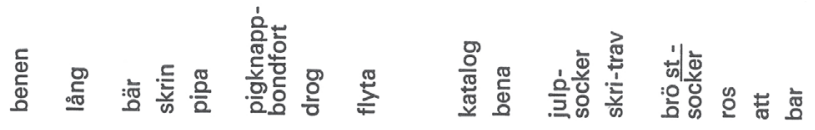
兴

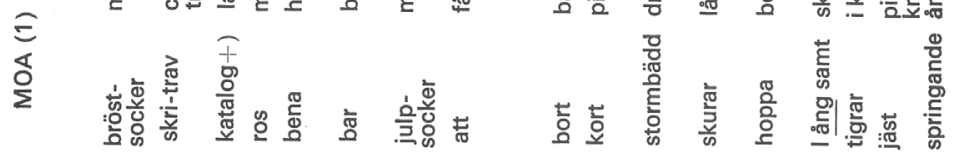

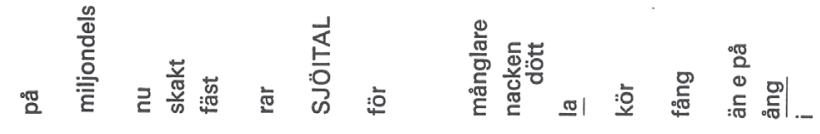

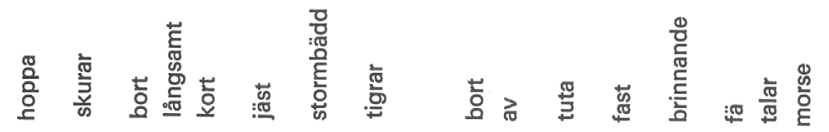

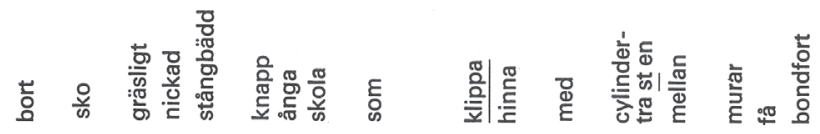

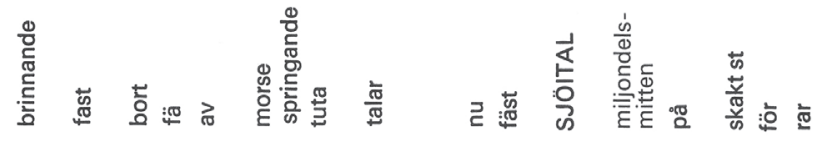

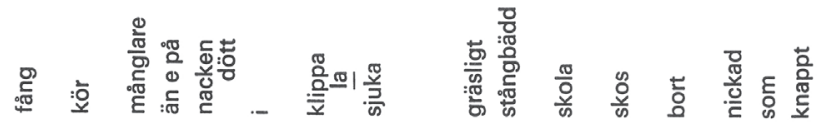




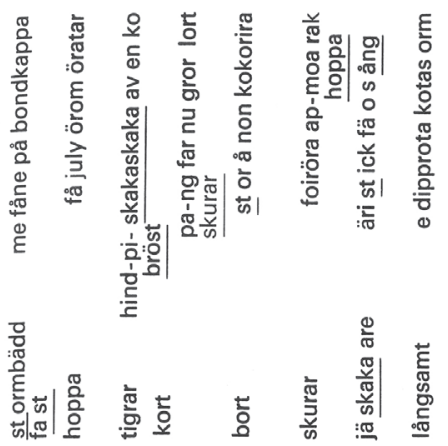

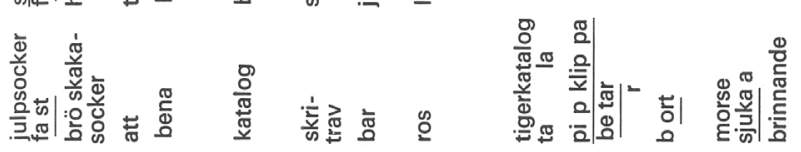

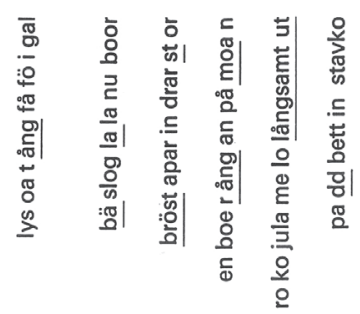

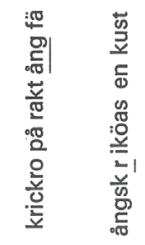

ำ

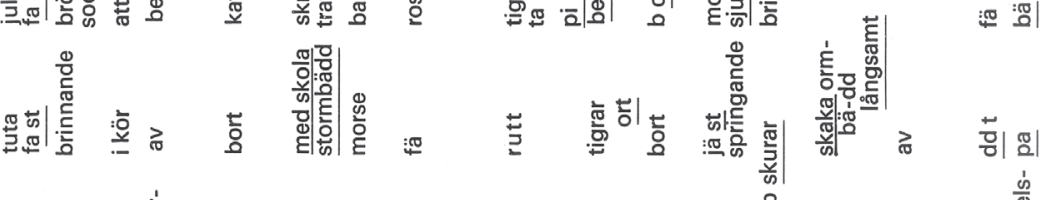

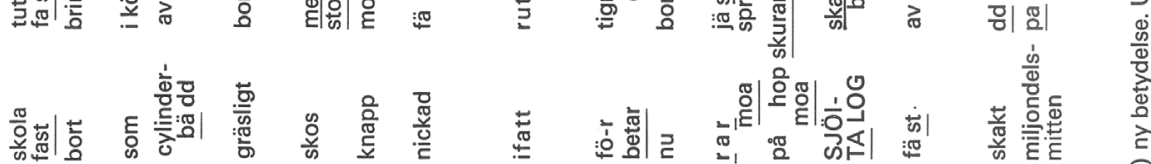

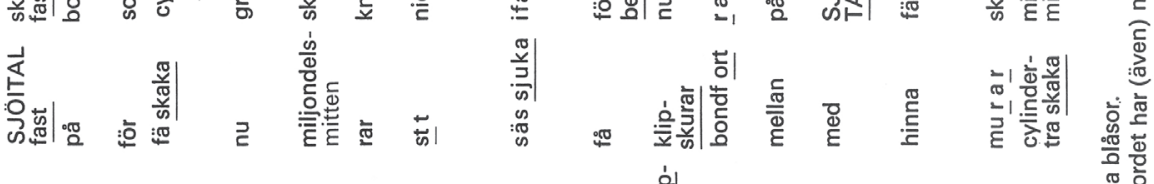

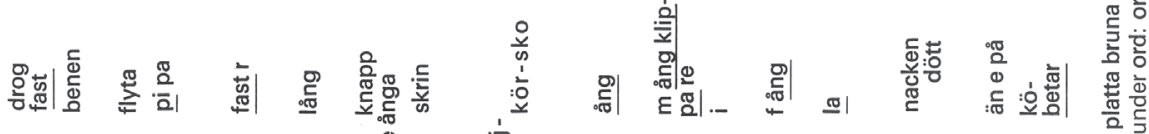

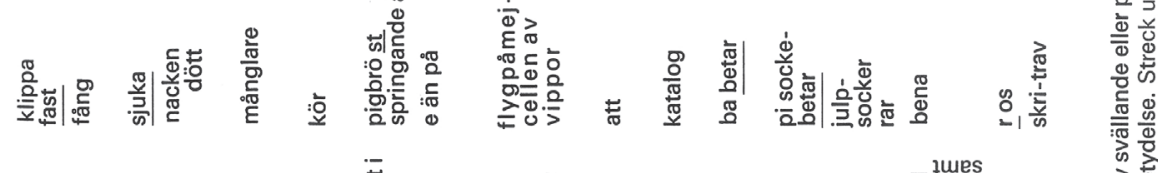

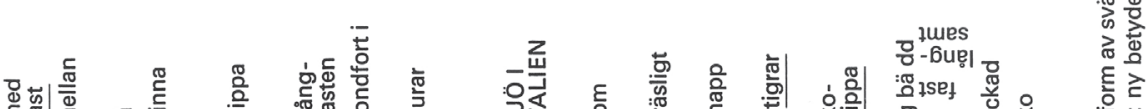

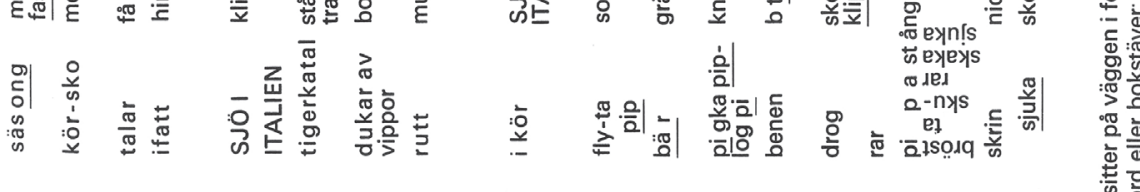

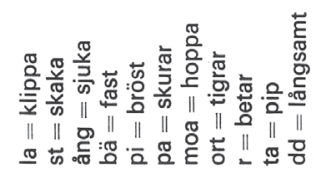

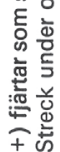

Picture 2. 


\section{NYÅRSKLOCKORNA}

Irroob asråas
be-a lo
aes be-år
se bloåål

åg

orrkkaarr

röra åt

bål

orkar

asråa

eka

bålet

röra

röra

epö

än

rbål räal

e vauoovb

bsoou asän

aer nubr

röra

röra

bål

voee lå

öon fbb

sura dråp bb

$r$ lo au nä yos

jpna reifou in

pbo å ouvbal

ao är

hy göbs

o-

andrum svalt

asynja svalt

ekar andrum låga

svällt

eka

åt

rör

svalt

eka

bålen

låg

orkar

åt

åt

låga

bålet

åt

låg

asråar

låga

vilt

arsråa

utslag

o-

orrkkaarr

vilt

bålet

bålet

slang

o-

orkar

utslagen andrum

svalt

än

nosar

aråar

eka

röra

nosar

utslag

bålet

rör 


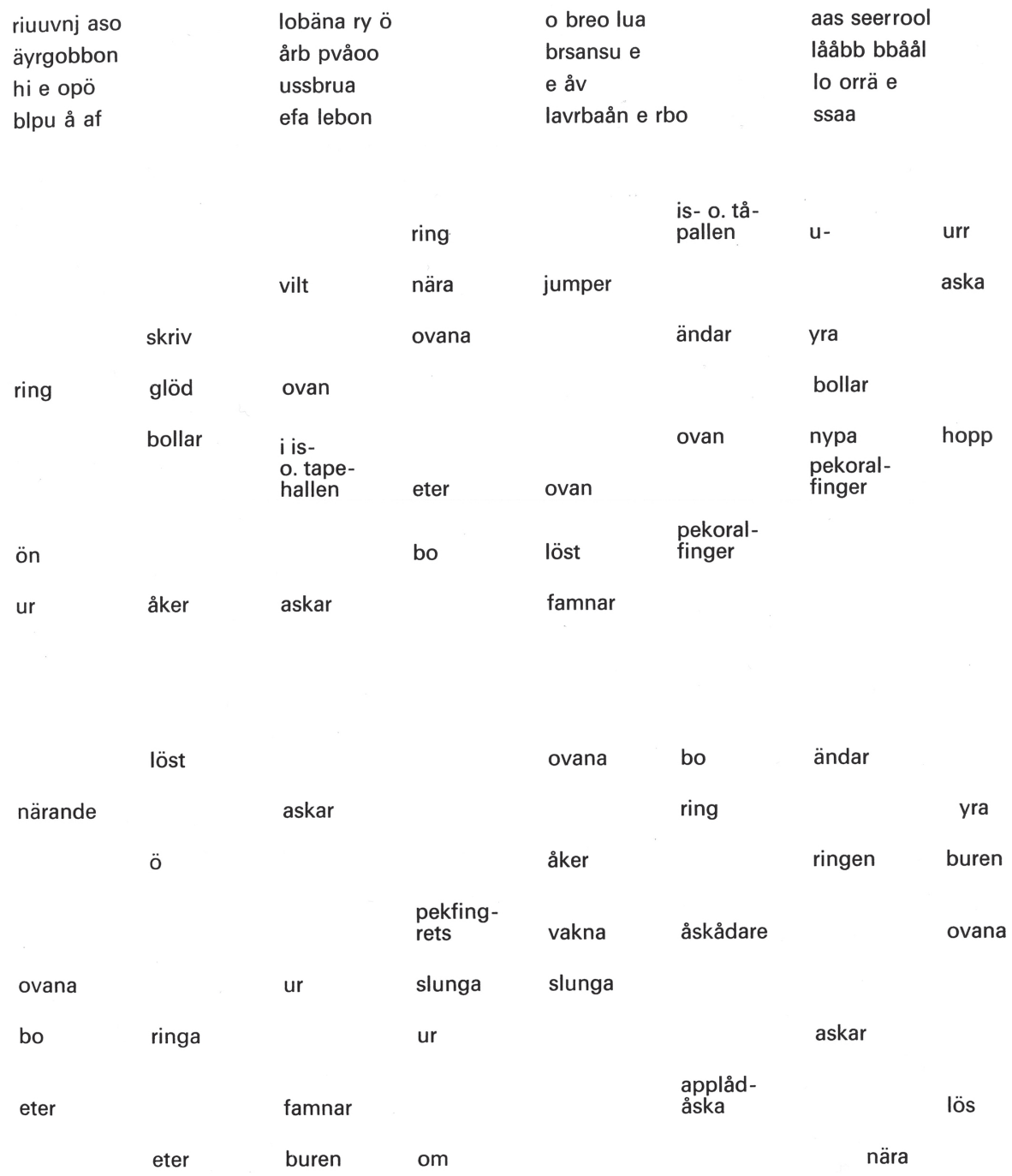

Picture 3. 


\section{MORGON I RÅDHUSET}

det börjar bli för mycket klubbar i Rådhuset

om vi tar bort hela världen t.ex. amalgamkänslor: han sitter gärna och skämtar, osv. och resten är l u $\mathrm{m} p$ med en stövare framför sitter han gärna och skämtar och resten är lu mp na och skämtar med en stövare framför na och skämtar sitter gärna och skämtar och skämtar

världen allt torrare och torrare och där bort om är allt lump badande som hjärtan i råttlökssolar för varje hjärta sprängs en klubb av en bonde: jag kän n er som hjärtan i råttlökssolar för varje hjärta hjärta sprängs en klubb lar för varje hjärta av en bonde : jag känner varje hjärta

hälften av botten i alla bönder höjs försök att hålla i mej när jag rusar fram genom klubben flytande bondfort av hela världen och hälften av lumpsolen jag sitter gärna med en stövare framför av hela världen och en stövare framför och hälften av lumpsolen jag sitter framför gärna med en stövare framför framför

bönder sträcks mot varandra i klubbarna i sina rökrockar en framför varje hjärta svettandes efter badet har dom rusat upp ur värld en och fått stenhårda hundar till hjärtan efter badet har dom rusat upp ur världen urvärlden och fått urvärlden stenhårda hundar till hjärtan ur världen

på dom sitter jag gärna och skämtar bortom mej och Rådhussolen är det tyst lite riven ost ryker genom luften och vänder sej på en femöring lump är amalgamkänslor när man tar bort alla klubbar i Rådhuset på en femöring alla klubbar i Rådhuset lump är amalgamkänslor när i Rådhuset man tar bort alla klubbar i Rådhuset

och sitter på botten och sätter stövare framför mej för att andas mitt hjärta så att världen håller sej borta från mina amalgamkänslor mitt hjärta så att världen håller sej håller sej borta världen håller sej från mina amalgamkänslor d en håller sej 
DEN SVÅRA RESAN (för blandad talkör)

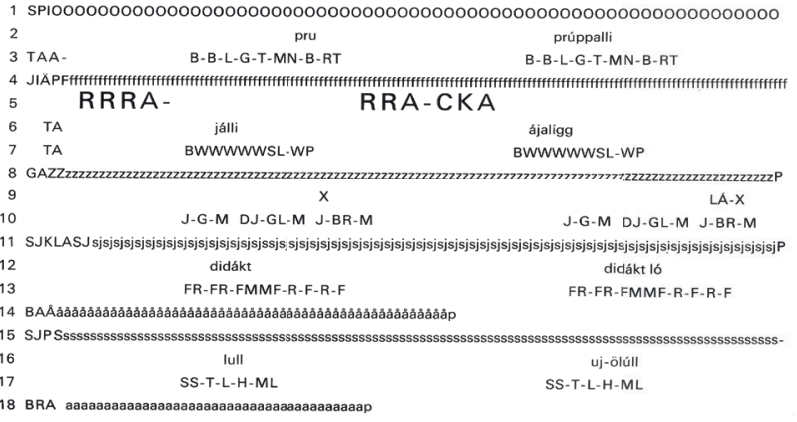

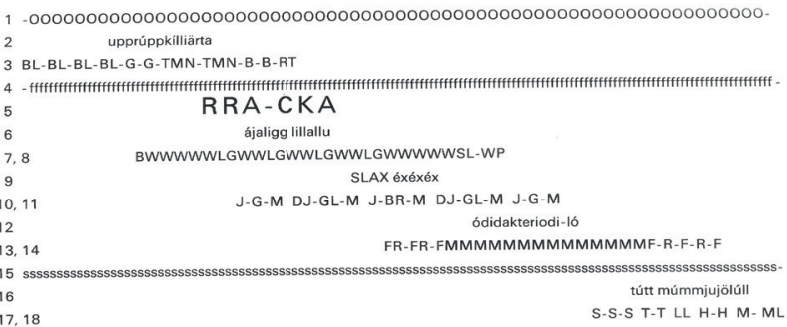

- 0000000000000000000000000000000000000000000000000000000000000000 úpprúppkillikärátta-OUM

3 BL-BL-BL-BL-G-G-TMN-TMN-B-B-RT

4 -

háiúllaligg lillalúgg

7.8. BWWWWWLGWWLGWWLGWWLGWWWWWSL-WP

2 rupprupprúppkillikäráttakäkráta

3, 8, 9, 10 BL-BL-BL-BL-G-G-BL-B-G-G-T-MN-T.

4 -ffffffpKI-TACK 